\title{
Shape Memory Materials: State of the Art and Requirements for Future Applications
}

\author{
J. van Humbeeck
}

Department MTM, K.U. Leuven, W. de Croylaan 2, 3001 Heverlee, Belgium

\begin{abstract}
NiTi is only one of many alloy systems that exhibit the shape memory effect. The reason of his success is only the fact that it is the best in many aspects. His large market share created a significant price reduction so that in combination with its good properties, it became a preferential alloy even when compared with $\mathrm{Cu}$-based alloys. Moreover NiTi alloys can be easily tuned to optimal performance by applying the proper combination of deformation and heat treatments. Its most successful applications are related to medical devices.

Nevertheless NiTi has also a few drawbacks: 1 . In spite of all the efforts to produce a NiTi based alloy with transformation temperatures above $150^{\circ} \mathrm{C}$, no successful material has been reported. 2. Because of the high Ni content, surgeons and physicians are still anxious to apply those materials as implants in the human body. 3. For some applications the price remains too high.

As a consequence, researchers are looking for alloy systems with high transformation temperatures, stable, reliable and with good strength and ductility. A combination of all those requirements is not realised yet, but significant progress has been made with $\mathrm{Cu}-\mathrm{Al}-\mathrm{Ni}$ and $\mathrm{Cu}-\mathrm{Al}-\mathrm{Be}$ single crystals. New alloy systems such as some B2 Zr-based intermetallics are also now investigated but are too brittle yet for use in appliances. Also some iron-based alloys retain specific attention. For Ni-less shape memory alloys, beta Ti-alloys are now investigated, but for good biocompatibility also $\mathrm{V}$ and $\mathrm{Al}$ have to be omitted in those alloys. Further interest remains in exploring new processing routes and even material properties that received only recently more attention.
\end{abstract}

\section{INTRODUCTION}

Shape memory materials are certainly not any longer the magic tools to impress ignorant decision makers or design engineers to get more research money for continuing basic research. It is worth notifying that those materials and their specific functional properties: memory effect, pseudo- or superelasticity, high damping capacity, have also entered the research domain of mechanical engineering, design offices of small and big companies and even chemical engineering. This expanded research interest from pure physical into chemical and mechanical has turned those alloys from a research curiosum into a new material, available and ready for use in many types of industrial activities.

This increasing demand for new applications and designs in different and expanding market segments has also set forward the need for constant quality and reliability. Consequently, in a world where technology changes rapidly, companies who made those alloys as (a part of) its core business, performed a significant internal research effort to produce quality products that can only be obtained from a high quality ingot and its further processing.

The collected know-how in this domain, kept secret by the owners, creates now the competitieve strength of those companies. Thanks to their efforts and believe in these materials shape memory materials remain a challenging research field also for researchers who are organised more towards long term projects and who's interest is more in explaining the observed performance than in final products.

As such, both groups, companies and fundamental research groups, have certainly a common interest in continuing their research and development efforts. 
In this paper we would like to identify the possible areas where R\&D can be performed without being exhaustive.

1. Classic shape memory alloys.

2. Potential shape memory alloys.

3. New processing techniques.

4. Specific research topics related to shape memory alloys.

\section{CLASSIC SHAPE MEMORY ALLOYS}

In spite of a large effort, $\mathrm{Cu}$-based alloys could not realise its promesses, mainly due to inherent problems such as stabilisation, poor ductility, lack of biocompatibility, relative poor corrosion resistance. Also the functional properties such as shape memory effect and pseudoelasticity are inferior to those of $\mathrm{Ni}-\mathrm{Ti}$ alloys. Moreover the price-advantage of the raw materials is overcome completely by the disadvantage of limited processing and small market penetration.

Similar remarks can be given to Fe-based shape memory alloys. The limits of $\mathrm{Cu}$-based and $\mathrm{Fe}$ based groups however should not be a limit to continue fundamental research on those type of alloys. Some alloys such as $\mathrm{Cu}-\mathrm{Al}-\mathrm{Ni}-\mathrm{Ti}-\mathrm{Mn}$ or $\mathrm{Cu}-\mathrm{Al}-\mathrm{Be}$ alloys are further investigated for use as high temperature shape memory alloys or pseudoelastic alloys. Also the stainless steel Fe-Mn-Si-Cr-Ni or Fe$\mathrm{Ni}-\mathrm{Co}-\mathrm{Ti}$ alloys have inherent potentials that requires further research.

For all classic alloy systems, literature is extremely extensive and a complete literature survey is certainly not the scope of this paper. For those interested in more detailed topics, a random walk trough the proceedings of international dedicated conferences can lead to excellent intriguing results. A list of more recent proceedings is given by reference [1] to [7].

And apart of those references, proceedings of other symposia especially those of MRS and I-UMRS are worth notifying.

Some of the items that will be discussed are also certainly valid for the other alloys systems. Since $\mathrm{NiTi}$ is the most important alloy, some important issues will be recalled, allowing the comparison with other alloy systems discussed further.

\section{Ni-Ti ALLOYS}

\subsection{Binary Ni-Ti alloys}

The science and technology is also here overwhelmingly documented. The influence of composition and thermomechanical processing on the functional properties is well understood and described in literature. The basic concept to remember is that in order to avoid plastic deformation during shape memory or pseudoelastic loading the martensitic and the $\beta$-phase have to be strengthened. This occurs by classic methods, strain hardening, solution and precipitation hardening. NiTi alloys have the significant advantage that these techniques can be easily applied due to good ductility and a very interesting but complicated precipitation process [8], [9].

\subsection{Ternary alloy systems}

Addition of third elements opens even more possibilities for adapting binary NiTi alloys toward more specific needs of applications. Adding a third element implies a relative replacement of $\mathrm{Ni}$ and/or $\mathrm{Ti}$. Therefore it must be always very well indicated which atom $\mathrm{Ni}$ or $\mathrm{Ti}$ or both is replaced by the third element.

Alloying third elements will influence not only the transformation temperatures but will also have an effect on hysteresis, strength, ductility, shape memory characteristics and also on the B2 $\rightarrow(R) \rightarrow(B 19)$ sequence. The influence of several elements have been already described in [10], [11], [12], [13], [14] and [15].

More application oriented, one can distinguish four purposes to add third elements:

1. to decrease $(\mathrm{Cu})$ or increase $(\mathrm{Nb})$ the hysteresis, 
2. to lower the transformation temperatures $(\mathrm{Fe}, \mathrm{Cr}, \mathrm{Co}, \mathrm{Al})$,

3. to increase the transformation temperatures ( $\mathrm{Hf}, \mathrm{Zr}, \mathrm{Pd}, \mathrm{Pt}, \mathrm{Au}$ ),

4. to strengthen the matrix (Mo, $\mathrm{W}, \mathrm{O}, \mathrm{C})$.

Some of the ternary alloys have been developed for large scale applications. We will only summarise the two most well developed: $\mathrm{NiTiCu}$ and $\mathrm{NiTiNb}$.

$\mathrm{Ti}-\mathrm{Ni}-\mathrm{Cu}$

Ternary $\mathrm{Ti}-\mathrm{Ni}-\mathrm{Cu}$ alloys in which mainly $\mathrm{Ni}$ is substituted by $\mathrm{Cu}$ are certainly as important as binary TiNi. Increasing $\mathrm{Cu}$-content decreases the deformation stress for the martensite state and decreases also the pseudoelastic hysteresis without affecting significantly the $M_{s}$-temperature [16]. However, more than $10 \% \mathrm{Cu}$ addition embrittles the alloys, hampering the formability.

It should also be remembered that while TiNi transforms from a B2 into a monoclinic phase, Ti-Ni$\mathrm{Cu}$ exceeding 15 at \% $\mathrm{Cu}$ transforms from a B2 into an orthorhombic phase. Ti-Ni-Cu with less than 15 at $\% \mathrm{Cu}$ transforms in two stages [17].

A disadvantage of most $\mathrm{Ti}-\mathrm{Ni}-\mathrm{Cu}$ alloys is that the transformation temperatures do not decrease below room temperature. In order to obtain pseudoelastic alloys at room temperature but with small hysteresis $\mathrm{Cr}$ or Fe can be alloyed. This way an $\mathrm{Ni}_{39.8} \mathrm{Ti}_{49.8} \mathrm{Cu}_{10} \mathrm{Cr}_{0.4}$ alloy has been developed with a small hysteresis (130 MPa), one fourth compared with $\mathrm{Ni}_{50} \mathrm{Ti}_{50}$ and $\mathrm{Ms}$ below room temperature [18].

$\mathrm{Ti}-\mathrm{Ni}-\mathrm{Nb}$ [19], [20], [21]

The inherent transformation hysteresis of NiTiNb is larger than for binary $\mathrm{Ni}-\mathrm{Ti}$ alloys. By the presence of a large dispersed volume fraction of deformable $\beta-\mathrm{Nb}$ particles, the hysteresis can be further widened by an over-deformation of stress-induced martensite, generally between Ms and Md. Originally NiTiNb (more specifically $\mathrm{Ni}_{47} \mathrm{Ti}_{94} \mathrm{Nb}_{9}$ ) was developed by Raychem Corp. [21] for clamping devices. The large shift of the reverse transformation temperatures from below to above room temperature by deformation, allows the room storage for open couplings.

Recently, also pseudoelastic $\mathrm{Ni}-\mathrm{Ti}-\mathrm{Nb}$ alloys have been developed with three significant differences relative to binary alloys $[20]$

- stress rate is much lower

- the $\sigma^{\mathrm{P}-\mathrm{M}}$ stresses are much higher

- the superelastic window is much larger

\section{POTENTIAL SHAPE MEMORY ALLOYS}

\section{1. $\beta$-Ti alloys}

In spite of the good biocompatibility of NiTi-alloys, doubts remain on the long term stability or on the danger of bad surface treatment leading to $\mathrm{Ni}$ leaching. Since $\mathrm{Ni}$ is known for his high allergic reaction, Ni-less shape memory alloys could be attractive. Such alloys might be developed based on the allotropic transformation in $\mathrm{Ti}$, a highly biocompatible material. Pure titanium shows an allotropic transformation from $\beta$ (bcc) to $\alpha$ (hexagonal) at $1265 \mathrm{~K}$. Transition elements (TM) stabilise the $\beta$-phase. Thus the temperature of the $(\alpha+\beta) / \beta$ transition decreases with increasing concentration of the alloying element.

$\beta$-phase Ti alloys can be martensitically transformed if they are quenched from the stable $\beta$-phase. Two types of martensite, respectively $\alpha^{\prime}$ and $\alpha^{\prime \prime}$ can be formed, depending on the composition and the solution treatment conditions [22].

The $\alpha^{c}$-martensite is hexagonal, while $\alpha^{\text {" has }}$ an orthorhombic structure [23]. It is the $\alpha^{\text {" }}$-martenite that shows the shape memory effect. The shape memory effect was first studied in detail by Baker in a Ti$35 \mathrm{wt} \% \mathrm{Nb}$ alloy [24]. Since then several observation of SME especially in Ti-Mo base alloys have been reported [25], [26], [27], [28], [29], [30]. A systematic work on the influence of different alloying elements on the shape memory effect can be found in [31], a patent deposited J. Albrecht, T. Duerig and D. Richter. 


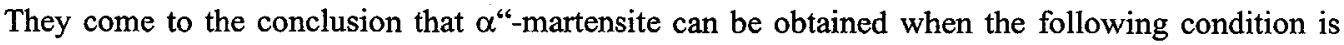
fulfilled:

$$
\perp_{1} 100 \leq \varepsilon\left(\mathrm{A}_{\mathrm{i}} \mathrm{X}_{\mathrm{i}}+\mathrm{B}_{\mathrm{i}} \mathrm{X}_{\mathrm{i}}^{2}\right) \leq-700
$$

where $X_{i}$ is the atomic percentage for each element, $A_{i}$ and $B_{i}$ are constants given in the patent for each element ( $\mathrm{V}, \mathrm{Al}, \mathrm{Fe}, \mathrm{Ni}, \mathrm{Co}, \mathrm{Mn}, \mathrm{Cr}, \mathrm{Mo}, \mathrm{Zr}, \mathrm{Nb}, \mathrm{Sn}, \mathrm{Cu}$ ). Ta was not claimed although it also offers its contribution to SME as described in [30].

Generally, a shape recovery in the order of $3 \%$ can be obtained based on strain-induced martensite and recovery stresses up to $170 \mathrm{Mpa}$ have been reported [29]. The disadvantage is that those alloys are very prone to stabilisation and decomposition due to the fact that the $\beta$-phase is retained after quenching in its metastable state and competes with $\omega$-phase during quenching. Also spinodal decomposition of $\alpha$ “martensite in $\mathrm{Ti}-\mathrm{Mo}$ and $\mathrm{Ti}-\mathrm{Nb}$ has been observed [22]. The sensitivity to decomposition at moderate temperatures is less, if not, important at room temperature. Therefor pseudoelastic $\beta$-Ti alloys could offer an interesting alternative to Ni-Ti alloys for example for orthodontic wires. Such alloy has been recently developed by Lei et al. [32]. Ti-11Mo-3Al-2V-4Nb was selected for further optimalisation. Excellent pseudoelasticity in the order of $3 \%$ was obtained after proper cold-working and heat-treatment.

\subsection{Alloys with high transformation temperatures}

Present shape memory alloys are limited to maximal $A_{f}$ temperatures of $120^{\circ} \mathrm{C}, \mathrm{M}_{\mathrm{s}}$ generally being below $100^{\circ} \mathrm{C}$. New designs have however revealed the need for materials that transform at much higher temperatures (above $150^{\circ} \mathrm{C}$ ) or where the martensite remains stable if exposed for very long term at high temperatures, generally combined with high recovery stresses. However, a major breakthrough is not reported yet mainly because of the following problems: stabilisation of martensite, decomposition of the parent or martensite phase, brittleness, price.

Table I summarises systems that are regularly reported in literature without being exhaustive. Some relevant references are indicated.

\subsection{Magnetic field induced martensite transformation}

T. Kakeshita et al. [51] have defined a magnetoelastic martensitic transformation: when a magnetic field is applied (above $A_{f}$ ) to the alloy exhibiting a thermoelastic martensitic transformation, martensite variants may be induced while a magnetic field is applied and revert to the parent phase when the magnetic field is removed. This has been observed in Fe-31.9 $\mathrm{Ni}-9.8 \mathrm{Co}-4.1 \mathrm{Ti}$ (at \%) [51], [52], [53].

But also other alloys are found in which a magnetic field can influence the martensitic transformation. Apart from other Fe-based alloys [54], $\mathrm{Ni}-\mathrm{Mn}$-Ga near the $\mathrm{Ni}_{2} \mathrm{MnGa}$ compound, which is a ferromagnetic Heusler ordered alloy, is one of the candidates [55], [56].

Beside the very interesting fundamental properties, those alloys could be able to act much faster than classic SMA-based actuators that are thermally driven. The band-width of those systems is limited to a few Herz (for very thin wires) due to cooling restrictions. In case of magnetoelastic martensitic transformations, band-widths of some orders larger could be obtained.

\subsection{Fe-based alloys}

Finally, the class of material where the story of martensite started long time ago should not be omitted. Although martensite of steels is certainly an order of magnitude more in use than martensite of shape memory alloys, a real breakthrough for Fe-based shape memory alloys has not been realised yet. Two alloy systems remain anyway as candidates for applications in the area of shape memory effect and even pseudoelasticity: Fe-Mn-Si and Fe-Ni-Co-Ti [57]. Recent literature, available in journals and conference proceedings $[1-7]$, show at least a steady progress in this matter. 


\begin{tabular}{|c|c|c|c|}
\hline \multirow{2}{*}{ Basic system } & \multicolumn{2}{|c|}{ Other alloying Elements } & \multirow[t]{2}{*}{ References } \\
\hline & Elements & Reason & \\
\hline \multirow[t]{2}{*}{$\mathrm{Cu}-\mathrm{Al}-\mathrm{Ni}$} & $\mathrm{Mn}$ & Control of TT, machinability & {$[33],[34]$} \\
\hline & $\mathrm{Ti}, \mathrm{B}, \mathrm{Zr}$ & Grain refinement to improve ductility & [35] \\
\hline \multirow[t]{2}{*}{ Ni-Ti-X } & $\mathrm{Pt}, \mathrm{Pd}, \mathrm{Au}, \mathrm{Rh}$ & $\begin{array}{l}\text { Based on B2 TiX compounds showing martensitic } \\
\text { transformation at high temperature }\end{array}$ & {$[36],[12]$} \\
\hline & $\mathrm{Hf}, \mathrm{Zr}$ & $\begin{array}{l}\text { Based on NiX compounds, forming a pseudobinary with } \\
\mathrm{NiTi}\end{array}$ & {$[37],[38],[39],[40]$} \\
\hline $\mathrm{Ni}-\mathrm{Al}$ & $\mathrm{Fe}, \mathrm{Co}, \mathrm{Mn}$ & To improve the ductility & {$[41],[42],[43],[44]$} \\
\hline \multirow[t]{2}{*}{ Ni-Mn } & $\mathrm{Al}, \mathrm{Ti}, \mathrm{Cu}$ for $\mathrm{Ni}$ & $\begin{array}{l}\text { To decrease } M_{S} \text { and to improve the shape memory } \\
\text { characteristics }\end{array}$ & {$[45],[46],[47]$} \\
\hline & $\begin{array}{l}\mathrm{Mg}, \mathrm{Al}, \mathrm{Si}, \mathrm{Ti}, \mathrm{V}, \mathrm{Sn}, \mathrm{Cr}, \mathrm{Co} \\
\mathrm{Fe}, \mathrm{Mo} \text { for } \mathrm{Mn}\end{array}$ & $\begin{array}{l}\text { To increase } M_{s} \text { and to improve the shape memory } \\
\text { characteristics }\end{array}$ & \\
\hline $\mathrm{CuZr}$ & $\mathrm{Ti}, \mathrm{Ni}, \mathrm{Co}$ & To decrease $\mathrm{M}_{\mathrm{S}}$ and to improve the ductility and stability & {$[49],[48],[50]$} \\
\hline
\end{tabular}

Table 1: High temperature shape memory alloys.

\begin{tabular}{|l|l|}
\hline Powder Metallurgy & {$[59],[60],[61],[104]$} \\
Combustion synthesis & {$[62],[63]$} \\
Porous material & {$[64],[65]$} \\
Thin film processing & {$[66],[67]$} \\
Melt spinning & {$[68],[69]$} \\
Laser cutting-etching & {$[70]$} \\
Welding & {$[71],[72]$} \\
\hline
\end{tabular}

Table 2: Alternative processing and machining of SMA alloys. 


\section{PROCESSING}

The technology of producing high quality NiTi alloys is certainly well established now. By double vacuum melting, this is induction melting followed by vacuum are melting, the oxygen and carbon content can be very well controlled. Hot working (forgeing, rolling), followed by cold working (wire drawing, rolling), eventually combined with heat treatments will finally lead to the required products. Apart from this classic way of processing, several other primary and secondary processing is investigated leading to semi-finished or even finished products. Especially the interest of microtechnology for very small ( $=$ thin) shape memory alloys has pushed the research on thin film production by vapor deposition, magnetron sputtering, laser ablation or melt-spinning. The interest for the shape memory alloys finds his origin in the very high power to weight ratio. For small devices shape memory alloys are far superior to other power delivering systems [58].

Other processing routes are powder metallurgy and combustion synthesis.

Regarding product finishing, special attention is given to machining, grinding, etching, laser cutting and welding. Information on the latter topics is less abundant and the main results are not available in public domain. Nevertheless, basic research could also here assist in improving the availability and implementation of shape memory alloy devices in more complicated systems.

For the interested reader, Table 2 summarises some recent references related to the different topics of processing.

\section{RESEARCH TOPICS FOR FURTHER EXPANSION OF SHAPE MEMORY ALLOYS}

Due to the expansion of the amount of applications and the inherent properties of shape memory materials, also quite a lot of other aspects apart from the classic functional properties, needs further attention. Most of those topics find their origin in emerging application fields that are briefly discussed in the following paragraphs.

\subsection{Biocompatibility of $\mathrm{Ni}$-Ti alloys}

The large success of especially superelasticity in the medical domain [73] has also revealed the need to pay attention to the biocompatibility of NiTi devices.

Fortunately, NiTi alloys are considered as high corrosion resistant, good biocompatible materials. Extensive in vivo experience in human bodies on implants, mainly related to dentistry, especially orthodontic wires, but also in orthopaedics, stenting or other medical branches has not revealed any special problem so far.

Regarding its biocompatibility NiTi can be compared with stainless steel (grade $316 \mathrm{~L}$ ), CoCr alloys and even pure $\mathrm{Ti}$. The origin of these properties is mainly related to the passivation layer of $\mathrm{TiO}_{2}$.

To reach a good passivation care must be taken for the final treatment in order to avoid small islands of pure $\mathrm{Ni}$ at the surface, or mixtures of $\mathrm{NiO}$ and $\mathrm{Ti}_{2} \mathrm{O}$, which may create favourite sites for selective dissolution $[74,75]$. In this respect surface conditions are extremely important. These surface conditions are controlled by the specific thermomechanical treatments that NiTi alloys have to pass in order to reach an optimal performance. Further processing and mounting should be done with care in order not to damage the $\mathrm{TiO}_{2}$ layer.

More detailed information and discussion on biocompatibility of NiTi alloys can be found in several references $[76,77,78,79,80,81,82]$.

\subsection{On the use of shape memory alloys in smart materials}

Shape memory alloys are considered as one of the important functional materials to act as actuator or sensor in so-called smart or intelligent materials [83].

There is an extended literature on the use of SMAs as discrete elements in diverse types of smart structures, but the literature on the integration of SMAs into polymer composites is not yet very extensive. First papers on SMA-composites were only published in 1988 [84]. A few review papers have been published in which different issues of SMA-composites are discussed [85, 86, 87]. These papers indicate 
that there are still many issues which require further research before SMA-composites can be used in industrial applications. A remarkable feature of the literature is a heavy bias towards modelling and presentation of concepts, with only limited attempts to experimental verification of the calculated results $[88,89]$.

Important issues to be investigated here is the quality of the interfaces between the shape memory elements and the matrix, as well as the constraining effect of the matrix on the martensitic transformation and related functional behaviour.

\subsection{The high damping capacity}

There is presently a large interest for damping seismic vibrations of buildings [90], [91], [92].

Since the strains can be very high, beyond the anelastic limit, two types of mechanisms are considered: energy absorption by pseudoelastic deformation and energy absorption by martensitic reorientation. Basically, in both cases no plastic deformation of the damping device is involved. The main difference between both is that in case of pseudoelasticity the deformation is recovered after unloading while in case of martensite reorientation the strain must be inversed to restore the shape of the damping device.

For those types of applications special attention must be given to maximize the energy absorption, to study the influence of strain rate, deformation amplitude, temperature and mode of deformation. This research is now part of a European BRITE-project [93].

\subsection{Other topics}

Shape memory alloys have definitely still much more to reveal. For example few is known on linear superelasticity, in which high elastic strains are obtained in cold worked $\mathrm{NiTi}$ [94], or dramatic changes in electrical resistance after martensite deformation or during pseudoelastic loading [95], [96], [97].

Other topics that can reveal more information and could assist in further improving the functional properties are fatigue [98] and texture [99], [100], [101].

\section{CONCLUSION}

Reliability and reproducibility in combination with the identification of the niche market has now turned shape memory alloys into rather common design materials. Design engineers have learned to work with non-linear materials. Shape memory companies control the complete processing in order to deliver the most appropriate material, fulfilling the requirements of functional properties of the SMA-part in a global design. Scientist are trying to reveal the fundamentals of the material behaviour and to identify the optimal material characteristics that might improve further SMA. At the same time there is the challenge to look for new or improved materials, stable at higher temperatures, with a better controlled hysteresis, with better biocompatibility or better fatigue life. Specific properties such as linear elasticity, damping, electrical resistance changes can lead to new applications in as far they can be adapted towards the specific needs.

It can be concluded that shape memory alloys have past their introductory state and are enjoying a significant growth. A good collaboration and understanding between users, producers and researchers can only enhance the interest for those anyway remarkable materials. At the other site, successful high-tech functional materials stimulate the search for competitive materials or techniques that replace either the material either the technique. Shape memory polymers [102] and even ceramics [103] are certainly potential candidates. 


\section{References}

[1] ICOMAT-95 proceedings, Part I and II, Lausanne 1995, Ed. Rolf Gotthardt and Jan Van Humbeeck, Editions de Physique, Journal de Physique, IV, Vol. 5, (8), France.

[2] ICOMAT-92 proceedings, Monterey CA, 1992, Ed. C.M. Wayman and J. Perkins, Monterey Inst. of Advanced Studies, Carmel, USA.

[3] ICOMAT-89 proceedings Part I and II, Sydney, Aus, 1989, Ed. B.C. Muddle, Trans Tech. Publications, Mat. Science Forum, Vol. 56-58, 1990.

[4] ESOMAT-94 proceedings, Barcelona, 1994, Ed. A. Planes, J. Ortin, L. Mañosa, Editions de Physique, Journ. de Physique IV, Vol. 5, C2, France.

[5] ESOMAT-91 proceedings, Aussois 1994, Ed. G. Guenin, Editions de Physique, Journ. de Physique IV, Vol. 1, C4, France.

[6] Proc. Int. Symp. on Shape Memory Alloys, 1994, Beijing, China, Ed. Chu Yougi, Tu Hailing, Int. Read Puclishers, 1994.

[7] SMST-Proceedings 1994, Ed. A. Pelton, D. Hodgson and T. Duerig, Ed. MIAS, 1994.

[8] M. Nishida, C.M. Wayman and T. Hanna, Met. Trans., 17A, (1986), pp. 1505-1515.

[9] D. Treppmann, E. Hornbergen and D. Wurzal, in ref. [1], pp. 569-574.

[10] K.H. Eckelmeyer, Scripta Met. 10, (1976), pp. 667-670.

[11] T. Honma, M. Matsumoto, Y. Shugo, I. Yamazaki, Proceedings ICOMAT-79, pp. 259-264.

[12] P. Kleinherenbrink, "On the martensitic transformation temperatures of NiTi and their dependence on alloying elements", $\mathrm{Ph}$. D. Thesis, Univ. Twente, 1991.

[13] V.I. Kolomytsev, in ref. [6], pp. 136-142.

[14] V.N. Kachin, Revue Phys. Appl. 24 (1989), pp. 733-739.

[15] V.N. Kachin, V.P. Voronin, V.P. Sivokha and V.G. Pushin, in ref. [1], pp. 707-712.

[16] T. Saburi, T. Takagaki, S. Nenno and K. Koshino, MRS Int'1. Mtg on Adv. Mats. Vol, 9, 1989, pp. 147-152.

[17] T. Saburi, MRS Int'l. Mtg. on Adv. Mats. Vol. 9, 1989, pp. 77-91.

[18] H. Horikawa and T. Ueki, Trans. Mat. Res. Soc. Jpn., Vol. 1813, (1993), pp. 113-116.

[19] K.N. Melton, J.L. Proft and T.W. Duerig, MRS Int'l Mtg. on Adv. Mats. Vol. 9, (1989), pp. 165170.

[20] J.H. Yang and J.W. Simpson, in ref. [1], pp. 771-777.

[21] J.A. Simpson, K.N. Melton, T.W. Duerig, USA Patent Nr. 4770725.

[22] E.W. Collings: "The Physical Metallurgy of Titanium Alloys", Ed. ASM series in Metal Processing, 1984, ISBN O - $87170-181-2$.

[23] O.M. Ivasishin, N.S. Kosenko and S.V. Shevskenko, in ref. [1], pp. 1017-1022.

[24] C. Baker, Metal Science Journal, 5, (1971), pp. 92 -100.

[25] H. Sasano, T. Suzuki, $5^{\text {th }}$ Proc. Int. Conf. of Titanium, 1988, Vol. 3, pp. 1667-1674.

[26] T. Harnada, T. Sodeoka and M. Miyagi, Proc. Int. Conf. of Titanium, 1988, Vol. 2, pp. 877-889, Ed. de Physique.

[27] T. Sugimoto, M. Ikeda, S. Komatsu, K. Sugimoto and K. Kamei, Proc. Int. Conf. of Titanium, 1988, Vol. 2, pp. 1064-1074.

[28] T.W. Duerig, J. Abrecht, D. Richter and P. Fisher, Acta Met. 30, (1982), pp. 2161-2172.

[29] T. Sohmura and H. Kimura, Proc. ICOMAT-86, NARA, Ed. JIM, pp. 1065-1070.

[30] S.G. Fedokov, T.V. Chelidze, Y.K. Kovernistyy and V.V. Sanadze, Phys. Met. Metall, 62, (1986), pp. 109-113.

[31] "Europaïsche Patentanmeldung 0062365, anmeldetag 11.03.1982".

[32] C.Y. Lei, M.H. Wu, L. McD. Schetky and C.J. Burstone, Proc. Wayman-Symosium, May 1996, to be published.

[33] I. Hurtado, P. Ratchev, J. Van Humbeeck and L. Delaey, Acta Met., Vol. 44, 8, (1996), pp. 32993306. 
[34] K. Sugimoto, K. Kamei and M. Nakaniwa in "Engineering Aspects of Shape Memory Alloys", Ed. T.W. Duerig et al., Butterwerth-Heineman, London, (1990), pp. 89-95.

[35] R. Elst, J. Van Humbeeck and L. Delaey, Mat. Sci. \& Techn., 4, (1988), pp. 644-648.

[36] S.M. Tuominen and R.J. Bierman, Journal of Metals (2), 1988, pp. 32-35.

[37] D.N. Abu judon, P.E. Thoma, M.Y. Kao and D.R. Angst, US Patent 5.114.504, 1992.

[38] Krupp GmbH, Fried., Essen, Patenschrift DE-4006076CI, 1990.

[39] J.H. Mulder, "Investigation of high temperature shape memory alloys from the Ni-Ti-Zr and NiTi-Hf systems". Ph.D. Thesis, Univ. Twente, 1995.

[40] P. Olier, J.C. Brachet, J.L. Rechade, C. Foucher and G. Guénin, in ref. [1], pp. 741-746.

[41] D.B. Miracle, Acta Met. Math. 41 (3), (1993), pp. 649-684.

[42] S. Furakawa, A. Ione, T. Masumoto, Mater. Sci. Eng. 98, (1988), pp. 515-518.

[43] K. Ishida, R. Kainuma, N. Ueno and T. Nishizawa, Metall. Trans. 22A (2), (1991), pp. 441-446.

[44] C.C. Law and S.M. Russel, Patent GB 2226047A, 1989.

[45] K. Adachi and C.M. Wayman, Metall. Trans. A, 16A (a), (1985), pp. 1567-1579 and pp. 1581-1597.

[46] W.S. Yang and D.E. Mikhola, MRS-Proc. Vol. 246, (1992), pp. 135-140.

[47] P.L. Potopov, Metal Science and Heat Treatment, Vol. 35, (1994), pp. 520-525.

[48] Yu. N. Koval, G.S. Firstov, J. Van Humbeeck and L. Delaey, Scripta Met. et Mat. 31, (7), (1994), pp. 799-802.

[49] Yu. N. Koval, G.S. Firstov, J. Van Humbeeck, L. Delaey and W.Y. Jang, in ref. [1], pp. 11031108.

[50] W.Y. Jang, J. Van Humbeeck, L. Delaey, Yu. N. Koval and G.S. Firstov, Trans. Mat. Res. Soc. Jpn. 18 b (Elsevier 1984), pp. 1009-1012.

[51] T. Kakeshita, T. Saburi and K. Shimizu, MRS-Boston, Dec. 1996, to be published.

[52] T. Kakeshita, K. Shimizu, T. Maki, I. Tamura, S. Kijma, M. Date, Scripta Metall. 19, (1985), pp. 973-976.

[53] T. Kakeshita and K. Shimizu, Trans. Mat. Res. Soc. Jpn, 18B, (1994), pp. 981-984.

[54] T. Kakeshita, K. Shimizu, M. Ono and M. Date, Journal of Magnetism and Magnetic Materials (1990), pp. 34-36.

[55] V.A. Chernenko, A. Amengual, E. Cesari, V.V. Kokorin and I.K. Zasimchuk, in ref. [4], pp. $95-$ 98.

[56] V.A. Chernenko, E. Cesari, V.V. Kokorin, I.N. Vitenko, Scripta Met. et. Mat., 33, (1995), pp. 239-244.

[57] T. Maki, Mat. Science Forum, Vls. 56-58, (1990), pp. 157-168.

[58] K. Ikuta, Proc. Conf. Rob. and Act, Ed. IEEE, (1990), pp. 2156-2161.

[59] T.W. Duerig, in ref. [7], pp. 31-36.

[60] H. Kato, T. Koyari, M. Tokizane and S. Miura, Acta Met. Mater. 42, (1994), pp. 1351-1358.

[61] J.C. Hey and A.P. Jardine, Mat. Sc. \& Eng., A 188, (1994), pp. 291-300.

[62] M. Zhu, T.C. Li, J.T. Liu and D.Z. Yang, Acta Met. Mat. 39, (1991), pp. 1481-1487.

[63] Hu Chun Yi and John J. Moore, JOM, August 1990, pp. 31-35.

[64] S.A. Shabalovskaya, V.I.Itin and V.E. Gyunter, in ref. [7], pp. 7-12.

[65] V.V. Skorohod, S.M. Solomi, I.F. Martynova and N.V. Klimenko, Science of Sintering 22 (2), (1990), pp. 21-28.

[66] Ref. [1], pp. $665-706$.

[67] A. David Johnson, J. Micromech. Microeng. 1 (1991), pp. 34-41.

[68] A.V. Sheylakov, Yu A. Bykonsky, N.M. Matneevo and Yu.K. Kovneristy, in ref. [1], pp. 713-716.

[69] X. Z. Wu, S.D. Wang, JP. Zheng, H.Q. Su, Scripta Met. et Mat. 31, (1994), pp. 53-56.

[70] M. Kohl, E. Quandt, A. Schlüssler, R. Trapp, D.M. Allen, Proc. Actuator 94, Ed. AXON Technology, pp. 317-320.

[71] P. Schlossmacher, T. Haas and A. Schüssler, in ref. [7], pp. 85-90.

[72] A.S. Schüssler, T. Haas, P. Schlossmacher, Proc. Actuator 94, Ed. Axon Technology, pp. 372-277.

[73] T.W. Duerig, A.R. Pelton and D. Stöckel, Metall, 9; (1996), pp. 569-574. 
[74] C.M. Chan, S Trigwell and T. Duerig, Surf. and Intern. Analysis 15 (1990), pp. 349

[75] Y. Oshida, R.C.L. Sachdeva and S. Miyazaki, Bio-Medical Materials and Engineering 2 (1992), pp. 51-59.

[76] L.S. Castleman, S.M. Molzkin, F.P. Alicandri, V.L. Bonavit and A.A. Johnson, J. Biomed. Mater. Res. 10 (1976), pp. 695-731.

[77] Y. Oshida, R. Sachdeva, S. Miyazaki and S. Fukuyo, Mat. Sc. Forum 56-58 (1990), pp. 705-710.

[78] Y. Oshida and S. Miyazaki, Corrosion Engineering 40 (1991), pp. 1009-1025.

[79] D.E. Catright, S.N. Bhaskar, R.M. Johnson and G.S.M. Corvan, Oral Surgery 35 (1973), pp. 578584.

[80] R.S. Dutta, K. Madangopal, H.S. Gadiyar and S. Banergy, British Corrosion Journal 28 (1993), pp. 217-221.

[81] S.A. Shabalovskaya, in ref. [1], pp. 1199-1204.

[82] T.W. Duerig, A.R. Pelton, D. Stöckel, Proc. Wayman Symposium, May 1996, to be published.

[83] M. V. Gandhi and B.S. Thompson "Smart Materials and Structures", Ed. Chapman \& Hall, 1992, ISBN 0412370107.

[84] C.A. Rogers, D.K. Barker, K.D. Bennett and R.H. Wynn (1988), SPIE-Vol. 386, pp. 90-105.

[85] J.S.N. Paine and C.A. Rogers "Adaptive structures and composite materials-analysis and application" Ed. E. Garcia, H. Cudney and A. Dasguptu, The American Soc. of Mech. Eng., New York, USA (1994), pp. 37-47.

[86] L. McD. Schetky, MRS-proceedings, Ed. Liu et al., USA, (1992), pp. 299-307.

[87] J.E. Bidaux, N. Bernet, C. Sarwa, J.-A.E. Månson and R. Gotthardt, (PR 1), pp. 1177-1182.

[88] C.M. Friend and N. Morgan, in ref. [1], pp. 415-420.

[89] R. Stalmans, J. Van Humbeeck and L. Delaey, Proc. Third ICIM/ECSSM'96, Lyon 1996, SPIEVolume 2779, pp. 511-516.

[90] A.S. Whittaker, R. Krumme, S.C. Sweeney, J.R. Hays, Constr. Eng. Research Lab., Champaign, IL, Repot No: CERL-TR-95/22, NTIS nr. AD-A300681/4/XAB.

[91] P.R. Witting, F.A. Cozzarelli, Nat. Center for Earthquake Engineering Research, Buffalo, N.Y., Report No: NCEER-92-0013, NTIS nr. PB93-116663/XAB.

[92] P.W. Clark, I.D. Aichen, H.J. Kelly, M. Higashino, R. Krumme, Univ. of California/Berkely Easthquahe Eng. Res. Center, Richmond, CA, USA, Proc. SPIE nr. 2445, (1995), pp. 241-251.

[93] BRITE-project nr. BE 95-2168, contract nr. BRPR-CT95-0031, MANSIDE.

[94] G.R. Zadno and T.W. Duerig in "Engineering aspects of shape memory alloys", Ed., T.W. Duerig et al., Butterworth-Heinemann, 1990, pp. 414-419.

[95] G. Airoldi, T. Ranuui and G. Riva, Journal de Physique IV, 1, (1991), pp. C4-439-444.

[96] G. Riva and G. Airoldi, in ref. [1], pp. 623-628.

[97] A. Takimoto in ref. [1], pp. 599-604.

[98] J. Van Humbeeck, Joumal de Physique IV, (1), (1991), pp. 189-197.

[99] J.H. Mulder, P.E. Thoma and J. Beyer, Zeitschrift für Metallkunde, 84 (8), (1993), pp. 501-508.

[100] J.H. Mulder, P.E. Thoma and J. Beyer, Materials Characterization, 32, (1994), pp. 161-168.

[101] H. Inoue, N. Miwa and N. Inakazu, Acta Mat., 44, (1996), pp. 4825-4834.

[102] "Shape Memory Polymers", Trans. Tech. Publ., (1991), Ed. Innnovation, Paris.

[103] P.E. Reys-Morell, Jyh-So Cherng and I.-Woi Chen., Journal of the Am. Ceramic Society, 71, (1988), pp. 648-657.

[104] J. San Juan, R.B. Pérez-Sáez, V. Recarte, I. Sáez-Ocáriz, M.L. Nó, O. Ruano, Proc. Third/CIM/ECSSM '96, Lyon ‘96, SPIE, Vol. 2779, pp. 469-474. 